\title{
Het rendement van vrijwillige interne en externe mobiliteit
}

\author{
Maurice Gesthuizen en Jaco Dagevos*
}

In deze bijdrage beantwoorden we drie vragen. In welke mate verandert men in Nederland vrijwillig van positie op de arbeidsmarkt, beïnvloeden objectieve en subjectieve kenmerken van het werk de kans op vrijwillige mobiliteit en leiden deze positiewisselingen tot een verandering in deze kenmerken? Analyses op de longitudinale databestanden van de Organisatie voor Strategisch Arbeidsmarktonderzoek (OSA) van 1986 tot en met 2002 laten zien dat vrijwillige positiewisselingen vaak voorkomen, zeker ten tijde van hoogconjunctuur. Objectieve baankenmerken als de beroepsstatus en het uurloon blijken vrijwillige mobiliteit niet te kunnen voorspellen, subjectieve beoordeling van de baan in zijn algemeenheid, het inkomen, de aansluiting tussen vaardigheden en werkinhoud, gewerkte uren, de inhoud en collega's en werkdruk daarentegen wel. Hoe slechter de 'subjectieve persoon-baanfit' hoe groter de kans op vrijwillige mobiliteit. Bovendien blijkt uit panelanalyses dat vrijwillige mobiliteit in veel gevallen leidt tot een verbetering van objectieve baankenmerken, en een minder negatieve beoordeling van de subjectieve persoon-baanfit. Ongunstige baankenmerken blijken daarmee belangrijke pushfactoren te zijn om de huidige arbeidspositie te verlaten, en deze stap sorteert, grosso modo, duidelijk rendement.

Trefwoorden: intragenerationele mobiliteit, baankenmerken, panelanalyse, rendement

\section{Inleiding}

De opbrengsten van werk spelen een belangrijke rol in het leven van mensen, niet enkel vanwege de inkomsten en de status die het werk met zich meebrengt, maar ook vanwege de inhoud van het werk zelf, de mogelijkheden tot persoonlijke ontwikkeling en de contacten met collega's (Kalleberg, 1977; Kalleberg \& Mastekaasa, 2001; De Beer, 2001). Algemeen geluk in het leven blijkt in belangrijke mate te worden bepaald door de tevredenheid die men weet te 'produceren' op het werk (Layard, 2005). Deze baantevredenheid straalt uit naar andere levensdomeinen en omgekeerd kan werkstress een negatieve invloed hebben op het leven buiten het werk.
Ook voor de maatschappij is een hoge mate van tevredenheid over de werksituatie van belang. Tevreden werknemers zijn productiever dan ontevreden werknemers (Wright \& Cropanzano, 2000; Judge et al., 2001), zodat een betere fit tussen persoonlijke baanvoorkeuren en daadwerkelijke baankenmerken zal resulteren in een hogere maatschappelijke productiviteitsscore. Bovendien mag worden aangenomen dat een hoge mate van werktevredenheid ziekteverzuim zal inperken en arbeidsongeschiktheid zal voorkomen.

Werknemers streven gedurende hun arbeidsmarktcarrière dus naar een optimale combinatie van opbrengsten van een baan en worden verondersteld op hun plaats te zitten wanneer

* Maurice Gesthuizen was tot april 2007 verbonden aan het Sociaal en Cultureel Planbureau (SCP) te Den Haag en werkt momenteel bij de sectie Methoden \& Technieken van de Radboud Universiteit Nijmegen. Jaco Dagevos is verbonden aan het Sociaal en Cultureel Planbureau. Deze bijdrage is gebaseerd op de SCP-publicatie Arbeidsmobiliteit in goede banen 
er een hoge mate van overeenstemming is tussen de kenmerken die men wenst in een baan, en de feitelijke kenmerken van de baan. Dit wordt ook wel een goede persoon-baanfit genoemd (Kristof-Brown, Zimmerman \& Johnson, 2005). Omdat werknemers in moderne westerse economieën naar een zo hoog mogelijke mate van baantevredenheid streven, veronderstellen wetenschappers vaak dat ongunstige objectieve baankenmerken, zoals een lage status of een laag inkomen, en een slecht gewaardeerde subjectieve persoonbaanfit, tot gevolg hebben dat men op zoek gaat naar een andere baan en dat men, wanneer de kans zich voordoet, ook daadwerkelijk vrijwillig van baan zal veranderen (Sørensen, 1975; Keith \& McWilliams, 1997). Ongunstige objectieve en subjectieve baankenmerken fungeren anders gezegd als pushfactoren.

Er zijn echter maar weinig studies waarin longitudinale datasets worden aangewend om deze causale relatie vast te stellen tussen ongunstige objectieve en subjectieve baankenmerken van een werknemer op een bepaald tijdstip, en de kans op vrijwillige mobiliteit op een later moment in diens arbeidsmarktcarrière. Een doel van dit onderzoek is deze relatie te onderzoeken. Daarvoor gebruiken we de jaren 1986 tot en met 2002 van het Arbeidsaanbodpanel van de Organisatie voor Strategisch Arbeidsmarktonderzoek (OSA; Fouarge et al., 2006). Met behulp van deze panelgegevens zullen we ten eerste nagaan in hoeverre de kans op vrijwillige interne en externe mobiliteit groter is bij een lage score op de objectieve baankenmerken beroepsstatus en uurloon. Ten tweede kijken we eveneens naar de invloed van een ongunstig gepercipieerde persoon-baanfit op het gebied van de baan in zijn algemeenheid, het inkomen, de aansluiting tussen vaardigheden en werkinhoud, de gewerkte uren, de inhoud en collega's, onregelmatige werktijden, werkdruk, lichamelijk zwaar werk, autonomie en burn-outklachten.

Eveneens sporadisch is het onderzoek dat vervolgens op longitudinale wijze nagaat in hoeverre deze mobiliteit rendeert. En daar waar het gebeurt, wordt vaak maar naar een smalle selectie van uitkomstvariabelen gekeken. Veel economisch en sociologisch onderzoek spendeert bijvoorbeeld enkel aandacht aan typische extrinsieke baankenmerken als status en inkomen (zie bijvoorbeeld Mincer, 1974; Sørensen, 1975; Blossfeld, 1986; Keith \& McWilliams, 1997; Dwyer, 2004). Bekend is echter dat intrinsieke baankenmerken, zoals omgang met collega's en de inhoud, eveneens belangrijke factoren zijn voor de waardering van de baan en dat de beslissing van werknemers om van baan te veranderen juist is ingegeven om een verbetering van dit type baankenmerken te bewerkstelligen. Andere onderzoekers kijken wel naar verschillen tussen mensen in de waardering van extrinsieke en intrinsieke baankenmerken, maar onderzoeken vervolgens niet of deze veranderen onder invloed van mobiliteit (Tolbert \& Moen, 1998; Johnson, 2001). Kalleberg en Mastekaasa (2001) vormen een belangrijke uitzondering. Zij stellen met behulp van twee golven van een Noors panel vast dat door vrijwillige mobiliteit de ontevredenheid over diverse aspecten van het werk (zoals salariëring, zekerheid en inhoud) afnam.

In deze bijdrage willen we meer inzicht verschaffen in de relatie tussen baankenmerken en vrijwillige mobiliteit, en de invloed van mobiliteit op verandering in deze baankenmerken. We formuleren drie onderzoeksvragen. De eerste is een beschrijvende en luidt: in welke mate verandert men in Nederland tussen 1986 en 2002 vrijwillig van baan (externe mobiliteit) of van functie (interne mobiliteit)? Deze vraag dient om na te gaan of het onderwerp van substantiële aard is. Immers, ook al is het rendement van vrijwillige mobiliteit hoog, komt het slechts weinig voor, dan heeft het op maatschappelijk gebied maar weinig te betekenen. Vraag twee en drie gaan vervolgens in op de hierboven aangekondigde relatie tussen baankenmerken en mobiliteit, en de invloed van mobiliteit op veranderingen in baankenmerken: in hoeverre beïnvloeden de objectieve baankenmerken beroepsstatus en uurloon en de subjectieve fit tussen persoon en baan de kans op interne en externe vrijwillige mobiliteit? En in welke mate leiden vrijwillige interne mobiliteit en vrijwillige externe mobiliteit tot een verbetering in objectieve baankenmerken en een minder ongunstige waardering van de fit tussen de persoon en de baan? 


\section{Theoretische achtergrond: determinanten en rendement van mobiliteit}

In mobiliteitsonderzoek onderscheiden onderzoekers verschillende typen determinanten, waaronder individuele kenmerken (aanbodzijde) en kenmerken van banen (vraagzijde) en institutionele kenmerken (kenmerken van de arbeidsmarkt, nationale context). Neoklassieke economen richten zich in deze hoofdzakelijk op de betekenis van individuele kenmerken, terwijl sociologen en meer institutioneel georiënteerde economen zich tevens richten op de betekenis van structurele kenmerken van de arbeidsmarkt. In enkele studies worden genoemde factoren in onderlinge samenhang bezien (bijvoorbeeld Blossfeld, 1986; Glebbeek, 1993, De Graaf \& Luijkx, 1997; DiPrete et al., 1997; Dagevos, 1998). Arbeidspsychologen richten zich bovendien veel op de invloed die de match tussen de wensen van de werknemer en de inhoud van de baan heeft op allerlei individuele houdingen en gedrag (KristofBrown et al., 2005). In deze bijdrage richten we ons vooral op de invloed van een selectie van objectieve en subjectief gewaardeerde baankenmerken, en controleren we in de analyseparagraaf zo veel mogelijk voor determinanten van andere orde.

De reden waarom we in dit onderzoek de determinanten van mobiliteit 'beroepsstatus' en 'uurloon' behandelen als objectieve baankenmerken, is dat voor deze baankenmerken later zal worden vastgesteld of mobiliteit ook tot vooruitgang leidt. Het is vooraf dan zinnig om na te gaan of een lage score op beide baankenmerken tot vrijwillige mobiliteit aanzet. Het antwoord op deze vraag is vooraf niet eenduidig. Enerzijds streven mensen ernaar zo veel mogelijk uit hun werk te halen (Sørensen, 1975; Keith \& McWilliams, 1997) en valt er voor werknemers met een lage beroepsstatus en weinig uurloon allicht nog veel te winnen. Beroepsstatus en uurloon zouden dan negatief samenhangen met vrijwillige mobiliteit. Anderzijds is het ook de vraag of de werknemers die deze plaatsen bezetten, over de vaardigheden en kwalificaties beschikken om hoger op de beroepsladder aan de slag te geraken (zie ook Gaspersz \& Ott, 1997). In dit laatste geval zouden beroepssta- tus en inkomen dus niet, of zelfs positief moeten samenhangen met vrijwillige mobiliteit.

In de arbeidspsychologie veronderstelt men dat de mate waarin de werkwensen van werknemers worden verenigd met de feitelijke kenmerken van de baan, aangeeft in hoeverre de betreffende werknemer op zijn of haar plaats zit. Hoe beter deze subjectieve persoonbaanfit is (de werknemer beoordeelt zelf de kenmerken van de baan en zijn of haar eigen wensen), des te sterker voelen ze zich bijvoorbeeld verbonden met hun bedrijf, zijn ze tevreden over de baan in het algemeen, en des te minder zijn ze geneigd te stoppen met het werk (Kristof-Brown et al., 2005). Andersom bezien leidt een slechte persoon-baanfit tot ontevredenheid, de wens tot vertrek, en uiteindelijk tot vrijwillige mobiliteit als men een passende andere baan weet te lokaliseren, en uiteindelijk te bemachtigen. We verwachten dan ook dat hoe minder tevreden werknemers zijn over specifieke aspecten van hun baan (zoals loon, werktijden, autonomie, inhoud en collega's, werkdruk, enzovoort; zie voor de complete lijst tabel 4), des te groter de kans is dat ze vrijwillig van baan dan wel van functie wisselen.

Om de invloed van deze objectieve en subjectieve baankenmerken goed vast te stellen, is het nodig rekening te houden met een aantal achterliggende oorzaken, die zowel de objectieve als subjectieve baankenmerken kunnen beïnvloeden, als vrijwillige mobiliteit. Waar het gaat om individuele kenmerken verwachten we in de eerste plaats dat werknemers met meer menselijk kapitaal, geïndiceerd door opleiding, cursussen, werkervaring/leeftijd, (Becker, 1964; Mincer, 1974) de leukere banen bezetten en daarom allicht hoger scoren op zowel objectieve als subjectieve baankenmerken. Maar mogelijk hebben ze door dit menselijk kapitaal tegelijkertijd meer kansen om vrijwillig van positie op de arbeidsmarkt te wisselen (zie ook Gaspersz \& Ott, 1997). Naar verwachting zijn er eveneens verschillen tussen mannen en vrouwen. ${ }^{1}$ Niet alleen blijken vrouwen vaker werkloos, minder te verdienen, en in lagere banen te werken dan mannen, ook hun promotiekansen komen vaak slechter uit de bus (Kraaykamp \& Kalmijn, 1997; Gesthuizen, 2004). Ook de 
huishoudensamenstelling kan de kansen op mobiliteit beïnvloeden. De aanwezigheid van een partner en kinderen zal mogelijk de geografische gebondenheid vergroten en daarmee de bewegingsruimte op de arbeidsmarkt verkleinen (Felmlee, 1982; Rosenfeld, 1992). En het is mogelijk dat juist deze geografische gebondenheid de weg naar leukere banen verspert.

Beschouwen we achterliggende factoren aan de vraagzijde van de arbeidsmarkt, dan nemen we in de eerste plaats aan dat mensen met een tijdelijk contract wel vaak van baan moeten wisselen en dit deels vrijwillig doen, omdat ze anticiperen op vertrek op korte termijn. Tegelijkertijd zijn tijdelijke banen gemiddeld mogelijk minder aantrekkelijk. Ten tweede wordt vrij algemeen aangenomen dat interne arbeidsmarkten vaker voorkomen bij grotere bedrijven (Baron \& Bielby 1984; Althauser \& Kalleberg, 1990). Voor positieverandering zijn werknemers in kleine bedrijven meer aangewezen op de externe markt. Als er binnen grote bedrijven dan meer mogelijkheden zijn om leuke banen te bemachtigen, bepaalt ook bedrijfsgrootte zowel de kans op mobiliteit als objectieve en subjectieve baankenmerken. Van sectoren is ook bekend dat ze verschillen qua dominante loopbaanpaden (zie bijvoorbeeld Stinchcombe, 1979 en Glebbeek, 1993) en dat daarmee mobiliteitskansen ook variëren. Bovendien is in sommige sectoren meer hoogwaardig werk te vinden dan in andere, waardoor zowel objectieve als subjectieve kenmerken van banen hoogstwaarschijnlijk verschillen tussen sectoren. Tot slot dient de samenhang tussen baankenmerken en mobiliteit ook te worden gezuiverd voor de stand van de economie. Ten eerste is er ten tijde van laagconjunctuur (hoge werkloosheid, weinig economische groei) minder ruimte op de arbeidsmarkt om te wisselen van baan of functie en ligt het algemene vrijwillige mobiliteitsniveau dus lager. Bovendien zijn er dan ook minder opties om die perfect passende baan te bezetten, waardoor de kans op een ongunstige score op objectieve en subjectieve baankenmerken groter wordt.

Een algemene propositie luidt dat werknemers in het werkleven streven naar een zo hoog mogelijke intrinsieke en extrinsieke 'beloning'. Vrijwillige mobiliteit is een manier om dit te bereiken (Sørensen, 1975). Werknemers anticiperen vaak op een verbetering van de werksituatie en veranderen van baan of functie als de kans hierop groot is (Keith \& McWilliams, 1997). Vrijwillige mobiliteit is dus, zo veronderstellen we, veelal doelgericht: werknemers initiëren baan- of functiewisselingen, omdat ze daardoor een hoger loon of gunstigere werktijden kunnen bemachtigen, leukere collega's krijgen, een functie met een meer uitdagende inhoud en wat dies meer zij. Voor Noorwegen onderzochten Kalleberg en Mastekaasa (2001) of tussen 1989 en 1993 de subjectieve beoordeling van de salariëring, de zekerheid van het werk, het plezier in het werk en de inhoud van het werk, voor vrijwillig mobiele werknemers (movers) in positieve zin veranderde in vergelijking met niet-mobiele werknemers (stayers). Op beide meetmomenten was dus gevraagd een beoordeling te geven, en een deel van de groep bleek tussen 1989 en 1993 te zijn veranderd van baan. Vrijwillige mobiliteit sorteerde duidelijk effect. Zo'n opzet hanteren we hier ook voor Nederland, maar dan met meer meetmomenten (9 golven; 1986-2002) en ook meer baankenmerken (zie tabel 4) en we verwachten dat voor vrijwillig mobiele werknemers tussen twee tijdstippen de toename in objectieve baankenmerken (inkomen, status) relatief sterker is dan voor nietmobiele werknemers, en de afname van een ongunstig gewaardeerde persoon-baanfit sneller.

\section{Data}

We beantwoorden de vragen door gebruik te maken van het Arbeidsaanbodpanel van 1986 tot en met 2002 van de Organisatie voor Strategisch Arbeidsmarktonderzoek (OSA; Fouarge et al., 2006). Dit tweejaarlijkse panel bevat per peilmoment informatie over objectieve kenmerken van de baan (inkomen, beroepsstatus) en de wijze waarop werknemers (aspecten van) hun baan ervaren. Het is dus mogelijk om veranderingen in baankenmerken vast te stellen. Tevens is in ieder interview aan de respondent gevraagd de arbeidscarrière van de afgelopen twee jaar te beschrijven. Zodoende is bekend of men tus- 
sen twee peilmomenten van baan of functie veranderde. Steeds worden per golf ongeveer 4.000 actieve of inactieve leden van de beroepsbevolking ondervraagd. Er is sprake van een redelijk sterke mate van paneluitval: een derde van de respondenten doet de volgende golf niet meer mee. Deze worden vervangen door nieuwe panelleden, wier kenmerken tezamen een afspiegeling zijn van de bevolking in het betreffende jaar. ${ }^{2}$ Hierdoor zijn er voor twee opeenvolgende golven steeds voldoende respondenten aanwezig om de analyses te kunnen uitvoeren, en berusten de analyses op een steekproef die steeds representatief is voor het jaar waarin de vragenlijsten zijn afgenomen. Gemiddeld gaat het om 2.800 individuen per combinatie van twee golven, waarvan er in de meeste gevallen ongeveer 1.500 overblijven wanneer de op beide momenten in loondienst werkenden worden geselecteerd, en rekening wordt gehouden met ontbrekende waarden.

De reden waarom we deze selectie van jaren gebruiken van het OSA-Arbeidsaanbodpanel is ten eerste dat pas vanaf 1988 onderscheid wordt gemaakt tussen interne en externe mobiliteit. Omdat de oorzaken en gevolgen van mobiliteit kunnen verschillen tussen beide typen, is het van belang ze afzonderlijk te operationaliseren. Omdat we de causale invloed van baankenmerken op mobiliteit willen vaststellen, gecontroleerd voor andere typen determinanten, is 1986 het eerste jaar dat we nodig hebben. Gegevens gevraagd in dit jaar (bijvoorbeeld opleiding, baankenmerken, sector, enzovoort) worden dan gekoppeld aan gegevens uit het peilmoment daarna, waarin op retrospectieve wijze is vastgesteld of men de afgelopen twee jaar van baan of functie wisselde. Zo ontstaat de panelstructuur die we in deze gehele bijdrage hanteren.

Een deel van de analyses zal enkel worden uitgevoerd op de combinatie van de peilmomenten 2000 en 2002. De reden hiervan is dat deze twee jaren een uitgebreide batterij vragen bevatten over de subjectieve waardering van een groot aantal kenmerken van de baan. Dit biedt de mogelijkheid om voor inhoudelijk interessante baankenmerken veranderingen gedurende de loopbaan vast te stellen, als gevolg van vrijwillige mobiliteit. Bij de beschrijving van de meetinstrumenten komen we hierop terug; daar zullen we duidelijk aangeven over welke baankenmerken we beschikken voor de gehele periode van 1986 tot en met 2002, en enkel voor 2000-2002.

\section{Meetinstrumenten}

Voor vrijwillige mobiliteit onderscheiden we twee typen, namelijk een verandering van functie binnen het bedrijf, vrijwillige interne mobiliteit, en een verandering van werkgever, vrijwillige externe mobiliteit. Om de vrijwillig mobiele werknemers over te houden, hebben we alle gedwongen - door de werkgever geïnitieerde - vormen van mobiliteit uit de databestanden verwijderd. Het gaat hier om veranderingen van baan of functie vanwege reorganisatie of sluiting van een bedrijf(sonderdeel), het aflopen van een tijdelijk of uitzendcontract, (dreiging van) ontslag om een andere reden, en het gedeeltelijk arbeidsongeschikt of ongezond geworden zijn.

We gebruiken twee variabelen om objectieve baankenmerken vast te stellen, die bovendien op vergelijkbare wijze beschikbaar zijn voor 1986 tot en met 2002. Ten eerste is dit het $\log$ uurloon. Dat is berekend door het nettomaandloon te delen door het aantal uren dat men werkt per maand en er een logtransformatie op toe te passen. Sociaaleconomische beroepsstatus (ISEI; Ganzeboom, De Graaf \& Treiman 1992) is een rangordening van beroepsgroepen die tot stand komt door middel van hun gemiddelde opleidings- en inkomensniveau. De oorspronkelijke reikwijdte van 10 tot 90 is door middel van een lineaire transformatie teruggebracht naar een continue variabele die varieert tussen 0 en 1.

De baankenmerken die kunnen worden getypeerd als 'subjectieve persoon-baanfit' operationaliseren we zodanig dat een hogere score wijst op een, zo veronderstellen wij, slechtere overeenstemming tussen gewenste en feitelijke baankenmerken. Dit is het geval wanneer werknemers aangeven ergens ontevreden over te zijn, iets als belastend ervaren, of anderszins een baankenmerk als negatief typeren. Vier zijn er beschikbaar voor de gehele periode 1986-2002. Dit zijn in de eerste 
plaats ontevredenheid over de baan in het algemeen en ontevredenheid over het inkomen, en deze omvatten vier antwoordmogelijkheden: zeer tevreden, wel tevreden, niet zo tevreden en helemaal niet tevreden. De derde, ontevredenheid over de aansluiting, berust op de vraag: hoe sluiten uw kennis en vaardigheden en uw werk bij elkaar aan? De antwoordmogelijkheden waren goed, redelijk, matig en slecht. In de vragenlijst zijn eveneens de vragen opgenomen over het werkelijke aantal uren dat men werkt en het gewenste aantal uren. Komen deze niet overeen, dan veronderstellen we dat de respondent ontevreden is over het gewerkte aantal uren.
Een deel van de subjectieve persoon-baanfitvariabelen is, zoals gezegd, alleen beschikbaar voor de peilmomenten 2000 en 2002. Omdat het over een groot antal indicatoren gaat, hebben we ervoor gekozen middels factoranalyse datareductie toe te passen. De oplossing hiervan staat in tabel 1 , waarin de namen van de zes dimensies staan, alsmede de bewoording van de afzonderlijke items die aan alle eisen van een goede factoroplossing voldoen (voldoende hoge communaliteit, geen dubbellading). ${ }^{3}$

Zoals blijkt, levert de eindoplossing van de factoranalyse, waarin de items zodanig zijn opgenomen dat een hogere score een minder goede subjectieve persoon-baanfit indiceert,

Tabel 1 Dimensies van werk; de subjectieve beoordeling door de respondent van de fit tussen feitelijke en gewenste kenmerken van de baan, principale factoranalyse, voormeting $2000^{a}, R^{2}=42,9 \%$ (bron: OSA Arbeidaanbodspanel 2000-2002)

\begin{tabular}{|c|c|c|c|c|c|c|c|}
\hline & Com. & $\begin{array}{l}\text { Inhoud en } \\
\text { collega's }\end{array}$ & $\begin{array}{l}\text { Werk- } \\
\text { tijden }\end{array}$ & $\begin{array}{l}\text { Werk- } \\
\text { druk }\end{array}$ & $\begin{array}{l}\text { Lichamelijk } \\
\text { zwaar werk }\end{array}$ & Autonomie & $\begin{array}{l}\text { Burn-out- } \\
\text { klachten }\end{array}$ \\
\hline \multicolumn{8}{|l|}{ Gevoel gewaardeerd te worden } \\
\hline Voldoende ondersteuning van & & & & & & & \\
\hline leiding/werkgever & 0,66 & 0,80 & & & & & \\
\hline Er heerst een prettige sfeer & 0,39 & 0,56 & & & & & \\
\hline Ik heb inhoudelijk leuk werk & 0,29 & 0,44 & & & & & \\
\hline $\begin{array}{l}\text { Ik heb voldoende loopbaan- } \\
\text { perspectieven }\end{array}$ & 0,20 & 0,42 & & & & & \\
\hline Werken op zondag belastend? & 0,55 & & 0,72 & & & & \\
\hline Werken op zaterdag belastend? & 0,51 & & 0,70 & & & & \\
\hline Onregelmatige werktijden & & & & & & & \\
\hline belastend? & 0,44 & & 0,63 & & & & \\
\hline Ploegendienst belastend? & 0,37 & & 0,55 & & & & \\
\hline Ik werk onder hoge tijdsdruk & 0,61 & & & 0,77 & & & \\
\hline Ik heb het gevoel dat ik tijd & & & & & & & \\
\hline tekort kom & 0,49 & & & 0,68 & & & \\
\hline Geestelijk zwaar werk belastend? & 0,21 & & & 0,41 & & & \\
\hline Werk met gevaarlijke stoffen & & & & & & & \\
\hline belastend? & 0,34 & & & & 0,56 & & \\
\hline Stank op het werk belastend? & 0,33 & & & & 0,54 & & \\
\hline Gevaarlijke omstandigheden & & & & & & & \\
\hline belastend? & 0,31 & & & & 0,53 & & \\
\hline Lichamelijk zwaar werk belastend? & 0,25 & & & & 0,44 & & \\
\hline Zelf uitmaken inrichten werk & 0,60 & & & & & 0,73 & \\
\hline Zelf werktempo bepalen & 0,48 & & & & & 0,64 & \\
\hline Opgebrand door werk & 0,56 & & & & & & 0,61 \\
\hline $\begin{array}{l}\text { Vermoeid opstaan tijdens nieuwe } \\
\text { werkdag }\end{array}$ & 0,33 & & & & & & 0,52 \\
\hline Eigenwaarde & & 3,84 & 2,35 & 1,86 & 1,40 & 1,32 & 1,02 \\
\hline
\end{tabular}

a De factoroplossing van de nameting (2002) verschilt slechts in detail van bovenstaande oplossing van de voormeting (2000). De communaliteiten, dimensies/eigenwaarden, factorladingen en verklaarde variantie zijn vrijwel gelijk. 
zes factoren op met een eigenwaarde hoger dan 1. Voor deze zes dimensies hebben we de factorscores gebruikt als schaal. De minimale en maximale scores staan vermeld in tabel 3 en 4. De eerste dimensie is de waardering van de inhoud en collega's. Hoe hoger de score, hoe ongunstiger de subjectieve persoon-baanfit is. Opvallend is dat onderwerpen als loopbaanperspectieven, de sfeer op het werk, en waardering door de leiding, die naar onze verwachting redelijk onafhankelijk van elkaar zouden moeten zijn, toch gezamenlijk laden op deze dimensie. Blijkbaar vellen werknemers een oordeel over de werksituatie door deze aspecten in samenhang met elkaar te beschouwen. Onregelmatige werktijden is de tweede dimensie die naar voren komt. Werken in het weekend, in ploegendienst en op onregelmatige tijden bepaalt de score op deze dimensie. Items die tijdsdruk indiceren én belasting door geestelijk zwaar werk, indiceren tezamen de dimensie werkdruk. Ook belasting door lichamelijk zwaar werk en autonomie komen duidelijk naar voren als dimensie. De items, tot slot: 'ik voel me opgebrand door mijn werk' en 'ik voel me vermoeid als ik opsta en er weer een werkdag voor me ligt', wijzen op burn-outklachten.

De operationalisering van de variabelen tot slot, die als controlevariabelen worden opgenomen in de analyses, is te vinden in de eerste kolom van tabel 2 . Hierin staat aangegeven welke variabelen er zijn, welke categorieën ze hebben en wat, in het geval van continue metingen, de minimale en maximale waarden zijn.

\section{Methode}

De centrale analyses in dit onderzoek berusten op twee stappen. Eerst stellen we de causale relatie vast tussen objectieve baankenmerken en subjectieve persoon-baanfit enerzijds, en de kans op vrijwillige mobiliteit versus immobiliteit anderzijds. Omdat we vrijwillige mobiliteit zowel in zijn totaliteit beschouwen, als opgesplitst naar baan- en functiewisselingen, gaat het om zowel logistische als multinomiale logistische regressieanalyses. Om de causale volgorde tussen determinanten en mobiliteit met zekerheid te kunnen vaststellen, distilleren we de determinanten steeds uit peilmoment Tijd $T$, en mobiliteit steeds uit peilmoment Tijd $\mathrm{T}+1$. Het percentage werkloosheid en de economische groei berusten steeds op het jaar voorafgaande aan de meting van mobiliteit. Vond deze meting plaats in bijvoorbeeld 1996, dan berusten de indicatoren van werkgelegenheid op de totaalcijfers van 1995. Omdat sommige baankenmerken beschikbaar zijn voor de periode 1986-2002 en andere enkel voor 2000 en 2002, analyseren we de kans op vrijwillige mobiliteit voor deze verschillende perioden afzonderlijk.

Iedere keer dat een respondent in twee opeenvolgende peilmomenten aanwezig is, wordt hij of zij opnieuw opgenomen in de dataset. Dit betekent dat dezelfde personen vaker kunnen terugkeren, waardoor metingen niet meer onafhankelijk zijn van elkaar en standaardfouten worden onderschat. Dit is ondervangen (alleen in het 1986-2002-model, omdat het andere model maar twee meetmomenten kent) door middels de clusteroptie in STATA de standaardfouten te corrigeren voor afhankelijkheid.

Bovendien schatten we steeds twee modellen. Het eerste model bevat alle metingen van objectieve en subjectieve baankenmerken, behalve de ontevredenheid over de baan in zijn algemeenheid. Deze variabele wordt dan vervolgens toegevoegd. De reden is dat algemene baansatisfactie beschouwd kan worden als een variabele waarin de betreffende werknemer alle positieve en negatieve baankenmerken tegen elkaar heeft afgewogen, om zodoende tot een eindoordeel te komen. Het gezamenlijk opnemen van deze algemene indicator met specifiekere variabelen, zou de invloed maskeren die uitgaat van deze laatstgenoemde variabelen.

Een deel van de respondenten is in twee jaar meer dan eenmaal mobiel. We hebben besloten alleen de personen te selecteren die maar eenmaal vrijwillig mobiel waren (intern dan wel extern). De reden is dat we dan in de analyses waarin het rendement van mobiliteit wordt onderzocht, zeker weten dat de verandering in baankenmerken direct te koppelen is aan de mobiliteitsgebeurtenis. Hadden we 
na iedere baan- of functiewisseling naar de nieuwe baankenmerken gevraagd, dan hadden we de werknemers die vaker dan eenmaal mobiel zijn wel in de analyses kunnen betrekken. Overigens is op het totaalbestand slechts een marginaal deel vaker mobiel (ongeveer $4 \%)$.

Dit brengt ons bij de vervolgstap van de analyses: het rendement van mobiliteit. Van alle besproken baankenmerken hebben we gegevens voor minstens twee momenten. Als we het kenmerk op Tijd $\mathrm{T}+1$ als afhankelijke variabele nemen, terwijl we hetzelfde kenmerk op Tijd $\mathrm{T}$ aan de vergelijking toevoegen en we vervolgens de invloed van arbeidsmobiliteit bezien, dan drukt de mobiliteitscoëfficiënt de verandering in het baankenmerk uit als gevolg van deze verandering van arbeidsmarktpositie, ten opzichte van werknemers die in diezelfde periode niet mobiel waren. Een vereiste is dan wel dat deze positiewisseling tussen Tijd $\mathrm{T}$ en Tijd $\mathrm{T}+1$ plaatsvond. Zoals reeds aangegeven zorgt het retrospectieve design van de mobiliteitsvragen in het
OSA-panel hiervoor. Afhankelijk van het meetniveau van het baankenmerk gebruiken we lineaire, logistische of geordende logistische regressietechnieken. De analyses waarin de baankenmerken aan bod komen die op alle peilmomenten beschikbaar zijn, corrigeren we wederom voor clustering.

\section{Resultaten}

Het blijkt dat een niet te verwaarlozen deel van werknemers in loondienst vrijwillig van baan of functie wisselt in de twee jaar voorafgaand aan het moment van bevraging (figuur 1). Tussen 1986 en 1992 lag het percentage rond de 30, waarna het daalde naar ongeveer 15 midden jaren negentig. Daarna steeg het weer, maar niet meer tot de hoogte die werd bereikt eind jaren tachtig. Aan het eind van de vorige eeuw en in het begin van de huidige, veranderde een kwart van de werknemers vrijwillig van baan of functie. Duidelijk is dat vrijwillige mobiliteit veel vaker voorkomt ten tijde van hoogconjunctuur.

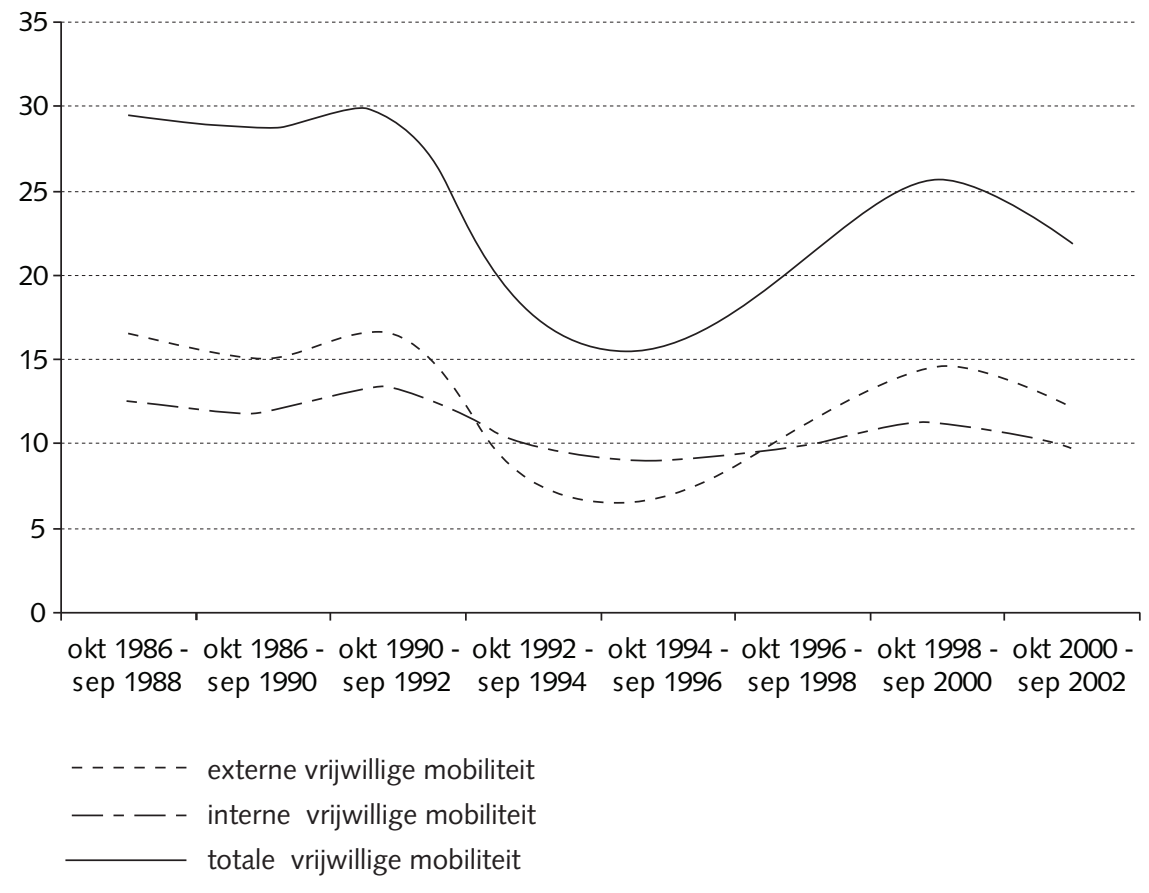

Figuur 1 De mate van vrijwillige externe en interne mobiliteit in Nederland 1986-2002 (bron: OSAArbeidaanbodspanel 1986-2002) 
In de meeste jaren blijkt het aandeel externe mobiliteit hoger dan het aandeel interne mobiliteit. Dit was niet het geval ten tijde van de economische laagconjunctuur begin en midden jaren negentig. Toen waren meer mensen intern mobiel dan dat er extern mobiele werknemers waren. Dit wijst erop dat vooral de kans op vrijwillige externe mobiliteit sterk wordt beïnvloed door de conjunctuur. De invloed van het percentage werkloosheid en economische groei in tabel 2 bevestigt dit beeld. Hoe hoger het werkloosheidspercentage in een bepaald jaar is, hoe kleiner de kans op een baanwisseling; hoe hoger het percentage economische groei is, hoe groter de kans. De reden dat in eerder gepubliceerde trends externe mobiliteit altijd meer voorkomt dan interne mobiliteit, is dat in tijden van laagconjunctuur veel mensen gedwongen van baan veranderen (zie Gesthuizen \& Dagevos, 2005). Deze groep werd in deze eerdere trends wel verdisconteerd.

Al met al is vrijwillige mobiliteit een niet te verwaarlozen fenomeen op de Nederlandse arbeidsmarkt, en daarmee dienen zich de vragen aan in hoeverre objectieve en subjectieve baankenmerken bijdragen aan de voorspelling ervan, en in welke mate daadwerkelijke positiewisselingen leiden tot een verbetering van objectieve baankenmerken en een minder ongunstige waardering van de subjectieve persoon-baanfit.

In tabel 2 en 3 presenteren we de resultaten die betrekking hebben op de invloed van baankenmerken op vrijwillige mobiliteit, na controle voor diverse andere determinanten van zowel mobiliteit als baankenmerken. ${ }^{4} \mathrm{De}$ hoogte van de beroepsstatus en het uurloon op Tijd $\mathrm{T}$ hebben geen invloed op welk type mobiliteitskans dan ook tussen Tijd T en Tijd $\mathrm{T}+1$. De baankenmerken die de subjectieve baan-persoonfit indiceren bepalen daarentegen in veel gevallen wel de kans op vrijwillige mobiliteit. Hoe meer ontevreden een werknemer is over het inkomen, de aansluiting tussen vaardigheden en de werkinhoud en over het aantal gewerkte uren, des te groter is de kans dat hij of zij vrijwillig van baan verandert. Ontevredenheid over de gewerkte uren verhoogt bovendien eveneens de kans op een vrijwillige positiewisseling binnen het bedrijf. De twee overige doen dat niet (zie tabel 2, modellen 1).

Algemene ontevredenheid over de baan blijkt zowel een goede voorspeller van vrijwillige externe als van vrijwillige interne mobiliteit, zij het voor baanwisselingen in sterkere mate dan voor functiewisselingen (tabel 2, modellen 2). Bovendien blijkt toevoeging van deze variabele vaak te leiden tot scherpe reducties in de effecten van de overige meer specifieke subjectieve baankenmerken op externe mobiliteit. De ontevredenheid over het inkomen blijkt nu zelfs niet meer significant te zijn. Deze bevinding wijst erop dat algemene baantevredenheid inderdaad de waardering in zich draagt van specifiekere baankenmerken. Daarmee is baansatisfactie een sterke voorspeller, maar inhoudelijk betrekkelijk weinig informatief.

Voor de zes dimensies (tabel 3) blijkt dat hoe ongunstiger de subjectieve baan-persoonfit is wat betreft de waardering van de inhoud en de collega's, hoe groter de kans is op vrijwillige mobiliteit. Dit geldt zowel voor vrijwillige externe als voor vrijwillige interne mobiliteit. Ook wanneer een werknemer de werkdruk als ongunstig ervaart, nemen de kansen op vrijwillige mobiliteit toe. In dit geval blijkt het vooral te gaan om vrijwillige mobiliteit binnen de organisatie. Een negatieve subjectieve waardering van de lichamelijke kracht die een baan kost, hangt eveneens samen met de kans op vrijwillige mobiliteit, maar in dit geval tegen de verwachting in op negatieve wijze. Een mogelijke verklaring is dat mensen die lichamelijk zwaar werk verrichten, weinig kans (denken te) hebben om in banen terecht te komen waar geen lichamelijke kracht voor nodig is. Ze zijn anders gezegd wellicht aangewezen op specifieke beroepsgroepen, die allen min of meer dezelfde kenmerken in zich meedragen. Dit zorgt er allicht voor dat ze eerder afzien van verandering van omgeving. Waarom moeite doen als er toch geen vooruitgang in zit?

Algemene ontevredenheid over de baan (modellen 2) blijkt vooral tot vrijwillige wisselingen van werkgever te leiden. Vooral de invloed van de ongunstige waardering van 
Het rendement van vrijwillige interne en externe mobiliteit

Tabel 2 De kans op vrijwillige mobiliteit (Tijd T+1), afhankelijk van objectieve baankenmerken, de subjectieve fit tussen feitelijke en gewenste baankenmerken en achtergrondkenmerken (Tijd T), 1986-2002, logistische en multinomiale logistische regressie met correctie voor clusteringa (bron: Arbeidsaanbodpanel 1986-2002)

\begin{tabular}{|c|c|c|c|c|c|c|}
\hline \multirow[b]{3}{*}{ Objectieve baankenmerken } & \multicolumn{2}{|c|}{$\begin{array}{l}\text { Vrijwillig mobiel } \\
\text { vs niet mobiel } \\
\text { (logistisch) }\end{array}$} & \multicolumn{2}{|c|}{$\begin{array}{l}\text { Extern vrijwillig } \\
\text { mobiel vs niet mobiel } \\
\text { (multinomiaal) }\end{array}$} & \multicolumn{2}{|c|}{$\begin{array}{l}\text { Intern vrijwillig } \\
\text { mobiel vs niet mobie } \\
\text { (multinomiaal) }\end{array}$} \\
\hline & model 1 & model 2 & model 1 & model 2 & model 1 & model 2 \\
\hline & & & & & & \\
\hline - beroepsstatus (0-1) & $-0,23$ & $-0,19$ & $-0,32$ & $-0,26$ & $-0,16$ & $-0,14$ \\
\hline - log uurloon $(-2,36-7,96)$ & $-0,03$ & $-0,02$ & $-0,15 \sim$ & $-0,14 \sim$ & 0,10 & 0,11 \\
\hline \multicolumn{7}{|l|}{ Subjectieve persoon-baanfit } \\
\hline - ontevredenheid baan algemeen (1-4) & & $0,27 * *$ & & $0,41 * *$ & & $0,11^{*}$ \\
\hline - ontevredenheid inkomen (1-4) & $0,08^{*}$ & 0,04 & $0,10^{*}$ & 0,04 & 0,05 & 0,04 \\
\hline - ontevredenheid aansluiting (1-4) & $0,09 * *$ & $0,06^{*}$ & $0,13 * *$ & $0,09 *$ & 0,05 & 0,03 \\
\hline - ontevredenheid gewerkte uren $(0 / 1)$ & $0,27^{* *}$ & $0,25 * *$ & $0,26^{* *}$ & $0,23 * *$ & $0,28 * *$ & $0,27 * *$ \\
\hline \multicolumn{7}{|l|}{ Leeftijd (ref. = 16-24 jaar) } \\
\hline - 25-34 jaar & $-0,34^{* *}$ & $-0,35^{* *}$ & $-0,44^{* *}$ & $-0,45^{* *}$ & $-0,09$ & $-0,10$ \\
\hline - 35-44 jaar & $-0,59 * *$ & $-0,61 * *$ & $-0,74^{* *}$ & $-0,77^{* *}$ & $-0,31 \sim$ & $-0,32 \sim$ \\
\hline - 45-54 jaar & $-1,14^{* *}$ & $-1,17^{* *}$ & $-1,32 * *$ & $-1,37^{* *}$ & $-0,83 * *$ & $-0,84^{* *}$ \\
\hline - 55-65 jaar & $-1,08^{* *}$ & $-1,10^{* *}$ & $-1,42^{* *}$ & $-1,45^{* *}$ & $-0,64^{* *}$ & $-0,65 * *$ \\
\hline \multicolumn{7}{|l|}{ Geslacht ${ }^{*}$ kinderen (ref. = man zonder kinderen) } \\
\hline - man met kind tot en met 12 jaar & $-0,12$ & $-0,10$ & $-0,20 \sim$ & $-0,17$ & $-0,06$ & $-0,05$ \\
\hline - man met kind van 13 jaar of ouder & $-0,32 * *$ & $-0,31 * *$ & $-0,47^{* *}$ & $-0,45^{* *}$ & $-0,23$ & $-0,22$ \\
\hline - vrouw zonder kinderen & $0,15 \sim$ & $0,15 \sim$ & 0,11 & 0,11 & 0,20 & $0,21 \sim$ \\
\hline - vrouw met kind tot en met 12 jaar & 0,06 & 0,07 & 0,05 & 0,07 & 0,04 & 0,06 \\
\hline - vrouw met kind van 13 jaar of ouder & 0,09 & 0,13 & 0,05 & 0,12 & 0,13 & 0,15 \\
\hline \multicolumn{7}{|l|}{ Burgerlijke staat (ref. = gehuwd, samenwonend) } \\
\hline - gescheiden & $0,26 \sim$ & 0,22 & $0,35 \sim$ & 0,28 & 0,16 & 0,15 \\
\hline - alleenstaand, verweduwd & $-0,23 * *$ & $-0,23^{* *}$ & $-0,22 \sim$ & $-0,22 *$ & $-0,27^{*}$ & $-0,26^{*}$ \\
\hline \multicolumn{7}{|l|}{ Hoogst voltooide opleiding (ref. = lagere school) } \\
\hline - vbo, mavo & 0,17 & 0,18 & 0,09 & 0,10 & 0,25 & 0,25 \\
\hline - mbo, havo, vwo & $0,32 * *$ & $0,31 * *$ & 0,19 & 0,18 & $0,44^{* *}$ & $0,44^{*}$ \\
\hline - hbo & $0,51 * *$ & $0,51 * *$ & $0,32 \sim$ & $0,30 \sim$ & $0,68 * *$ & $0,68 * *$ \\
\hline - wo & $0,55 * *$ & $0,54 * *$ & $0,55^{*}$ & $0,53 *$ & $0,55^{* *}$ & $0,55^{*}$ \\
\hline \multicolumn{7}{|l|}{ Cursussen (ref. = geen) } \\
\hline - door werkgever betaald & 0,07 & 0,07 & $-0,04$ & $-0,04$ & $0,15 \sim$ & $0,16^{*}$ \\
\hline - zelf betaald & 0,16 & 0,17 & 0,22 & 0,22 & 0,09 & 0,10 \\
\hline - zowel door werkgever als zelf betaald & $0,55^{* *}$ & $0,55^{* *}$ & $0,59 *$ & $0,57^{*}$ & $0,52 *$ & $0,52^{*}$ \\
\hline \multicolumn{7}{|l|}{ Contract (ref. = vast) } \\
\hline - tijdelijk & $0,52 * *$ & $0,53 * *$ & $0,81 * *$ & $0,81 * *$ & $-0,05$ & $-0,05$ \\
\hline - anders & 0,26 & 0,21 & 0,40 & 0,32 & $-0,01$ & 0,00 \\
\hline \multicolumn{7}{|l|}{ Bedrijfsgrootte (ref. $=500$ of meer) } \\
\hline - $1-9$ werknemers & $-0,15$ & $-0,13$ & 0,20 & $0,22 \sim$ & $-0,61 * *$ & $-0,60 * *$ \\
\hline - $10-19$ werknemers & 0,02 & 0,02 & $0,25^{*}$ & $0,25^{*}$ & $-0,21$ & $-0,20$ \\
\hline - 20-99 werknemers & $-0,16^{*}$ & $-0,16^{*}$ & 0,03 & 0,03 & $-0,32 * *$ & $-0,32 * *$ \\
\hline - $100-499$ werknemers & $-0,06$ & $-0,07$ & $-0,07$ & $-0,07$ & $-0,05$ & $-0,05$ \\
\hline \multicolumn{7}{|l|}{ Sector (ref. = kleinsch. handel en diensten) } \\
\hline - traditionele primaire sector & $-0,62 \sim$ & $-0,57 \sim$ & $-0,70^{*}$ & $-0,63$ & $-0,64$ & $-0,62$ \\
\hline - klassieke kapitalistische industrie & $-0,10$ & $-0,13$ & $-0,39 *$ & $-0,45 * *$ & 0,24 & 0,24 \\
\hline - geschoolde concurrerende industrie & $-0,07$ & $-0,08$ & $-0,2^{* *}$ & $-0,29 *$ & 0,22 & 0,21 \\
\hline - grootschalige bureaucratische industrie & $-0,07$ & $-0,08$ & $-0,42 * *$ & $-0,43 * *$ & $0,29 *$ & $0,29 *$ \\
\hline - professionele diensten & $-0,15 \sim$ & $-0,14 \sim$ & $-0,23^{*}$ & $-0,21^{*}$ & 0,02 & 0,02 \\
\hline - bureaucratische diensten & 0,05 & 0,05 & $-0,31^{*}$ & $-0,31 * *$ & $0,42 * *$ & $0,41 * *$ \\
\hline - missende waarde sector & 0,12 & 0,12 & $-0,05$ & $-0,04$ & $0,37^{*}$ & $0,37^{*}$ \\
\hline Percentage werkloosheid $(2,0-7,9)$ & $-0,06^{* *}$ & $-0,05^{* *}$ & $-0,12^{* *}$ & $-0,12 * *$ & 0,01 & 0,01 \\
\hline Percentage economische groei $(1,3-4,7)$ & $0,07 * *$ & $0,07 * *$ & $0,09 * *$ & $0,09 * *$ & $0,05 \sim$ & $0,05 \sim$ \\
\hline Constante & $-0,97 * *$ & $-1,34 * *$ & $-0,98 * *$ & $-1,54 * *$ & $-2,60 * *$ & $-2,76^{* *}$ \\
\hline Aantal & 9616 & 9616 & 9616 & 9616 & 9616 & 9616 \\
\hline Log likelihood & -4867 & -4835 & -6239 & -6194 & -6239 & -6194 \\
\hline
\end{tabular}

a Vanwege het panel design, waarvoor de jaren 1986 tot en met 2002 zijn gebruikt, zijn waarnemingen niet onafhankelijk van elkaar. Dezelfde personen komen immers vaker voor in het databestand. Wanneer niet wordt gecontroleerd voor deze afhankelijkheid, worden standaardfouten overschat en zijn effecten dus sneller, maar misschien wel ten onrechte, significant. Daarom is op deze modellen in STATA een clustercorrectie toegepast. Hierdoor zijn de standaardfouten robuust en bijgesteld voor de afhankelijkheid van waarnemingen.

$\sim \mathrm{p}<0,10$

* $p<0,05$.

** $p<0,01$. 
Het rendement van vrijwillige interne en externe mobiliteit

Tabel 3 De kans op vrijwillige mobiliteit (Tijd T+1), afhankelijk van de subjectieve fit tussen feitelijke en gewenste baankenmerken en achtergrondkenmerken (Tiid T), 2000-2002, logistische en multinomiale logistische regressie ${ }^{a}$ (bron: OSA-Arbeidsaanbodpanel 2000 en 2002)

\begin{tabular}{|c|c|c|c|c|c|c|}
\hline \multirow{3}{*}{$\begin{array}{l}\text { Subjectieve persoon-baanfit (Tijd T) } \\
-\quad \text { baan algemeen }(1-4)\end{array}$} & \multicolumn{2}{|c|}{$\begin{array}{l}\text { Vrijwillig mobiel } \\
\text { vs niet mobiel } \\
\text { (logistisch) }\end{array}$} & \multicolumn{2}{|c|}{$\begin{array}{l}\text { Extern vrijwillig } \\
\text { mobiel vs niet mobiel } \\
\text { (multinomiaal) }\end{array}$} & \multicolumn{2}{|c|}{$\begin{array}{l}\text { Intern vrijwillig } \\
\text { mobiel vs niet mobiel } \\
\text { (multinomiaal) }\end{array}$} \\
\hline & model 1 & model 2 & model 1 & model 2 & model 1 & model 2 \\
\hline & & $0,39 * *$ & & $0,50 * *$ & & 0,25 \\
\hline - inhoud en collega's $(-1,43-3,36)$ & $0,19 * *$ & 0,03 & $0,17 \sim$ & $-0,03$ & $0,21 *$ & 0,12 \\
\hline - werktijden $(-0,84-3,93)$ & 0,03 & 0,02 & $-0,03$ & $-0,05$ & 0,09 & 0,08 \\
\hline - werkdruk $(-1,90-2,03)$ & $0,22 *$ & $0,24^{* *}$ & 0,10 & 0,10 & $0,37 * *$ & $0,36 * *$ \\
\hline - lichamelijk zwaar werk $(-1,07-3,41)$ & $-0,22 * *$ & $-0,21^{* *}$ & $-0,24 \sim$ & $-0,26^{*}$ & $-0,21 \sim$ & $-0,22 \sim$ \\
\hline - autonomie $(-1,57-2,38)$ & 0,05 & 0,05 & $-0,01$ & $-0,02$ & 0,14 & 0,14 \\
\hline - burn-outklachten $(-1,63-3,16)$ & 0,11 & 0,01 & $0,21 \sim$ & 0,09 & $-0,03$ & $-0,09$ \\
\hline Constante & 1,00 & 0,34 & 0,89 & 0,04 & $-0,69$ & $-1,11$ \\
\hline Aantal & 1580 & 1580 & 1580 & 1580 & 1580 & 1580 \\
\hline Nagelkerke $\mathbf{R}^{2}$ & $10,2 \%$ & $11,2 \%$ & $12,2 \%$ & $13,1 \%$ & $12,2 \%$ & $13,1 \%$ \\
\hline
\end{tabular}

collega's en inhoud neemt af door de toevoeging van deze factor. Voor interne vrijwillige mobiliteit blijkt algemene ontevredenheid geen substantiële factor van betekenis. Blijkbaar zien mensen die echt ontevreden zijn over meerdere aspecten van de baan tegelijkertijd, weinig mogelijkheden om hiervoor intern oplossingen te vinden.

$\mathrm{Al}$ met al zijn er duidelijke aanwijzingen dat een ongunstige waardering van de persoonbaanfit resulteert in vrijwillige mobiliteit. Diverse ongunstig gepercipieerde aspecten van banen fungeren als pushfactoren, waarvan de mobiele werknemers verwachten dat ze in de nieuwe baan gunstiger uitpakken. In hoeverre dit het geval is, laten de resultaten van de analyses zien die in tabel 4 staan. In hoeverre stijgen scores op objectieve baankenmerken, en nemen ongunstige ervaringen over de subjectieve persoon-baanfit af, als mensen vrijwillig van baan of functie wisselen?

Zowel externe als interne vrijwillige mobiliteit leidt tot een stijging in de metingen van objectieve baankenmerken. Personen die extern vrijwillig mobiel zijn, stijgen één procent meer in beroepsstatus dan immobiele personen. Vrijwillige functiewisselaars stijgen wat betreft beroepsstatus zelfs 3 procent meer dan immobiele werknemers en eveneens 3 procent wat betreft het uurloon. De objectieve revenuen van vrijwillige mobiliteit zijn onmiskenbaar.

Hoe zit dat met de subjectieve revenuen? $\mathrm{Na}$ zowel externe als interne vrijwillige mobiliteit vermindert de ongunstige waardering van de baan in het algemeen in sterke mate. In beide gevallen neemt ook de ontevredenheid over het inkomen af en vertoont de waardering van de inhoud en collega's minder ongunstige scores dan voorheen. Bovendien leidt een vrijwillige wisseling van werkgever tot een afname in de werkdruk, wordt het werk als lichamelijk minder zwaar gepercipieerd en nemen eveneens de burn-outklachten af. Hiermee is al met al het rendement voor de subjectieve baan-persoonfit ook overtuigend aangetoond.

Een aantal resultaten vraagt nog wel om een korte nadere beschouwing. Allereerst is dat de bevinding dat vrijwillige externe mobiliteit niet tot een objectieve verhoging van het uurloon leidt, maar niettemin de ontevredenheid over het inkomen doet afnemen. Ervan uitgaand dat een werknemer de hoogte van het inkomen afzet tegen de taken die worden uitgevoerd, kan de evaluatie van de hoogte van het inkomen na verandering van baan beter 
Tabel 4 Gevolgen van vrijwillige externe en interne mobiliteit ten opzichte van immobiliteit (Tijd T) voor veranderingen in (de subjectieve fit tussen) feitelijke en gewenste baankenmerken, 1986-2002 en 2000-2002, diverse typen regressiemodellen ${ }^{a}$ (bron: OSA-panel 1986, 1988, 1990, 1992, 1994, 1996, 1998, 2000 en 2002)

\begin{tabular}{|c|c|c|}
\hline & Extern vrijwillig & Intern vrijwillig \\
\hline $\begin{array}{l}\text { objectieve baankenmerken (Tijd T+1) } \\
\text { - log uurloon }(0-1)^{b+e} \\
-\quad \text { beroepsstatus }(-2,36-7,96)^{b+e}\end{array}$ & $\begin{array}{l}-0,01 \\
0,01^{*}\end{array}$ & $\begin{array}{l}0,03^{*} \\
0,03^{* *}\end{array}$ \\
\hline 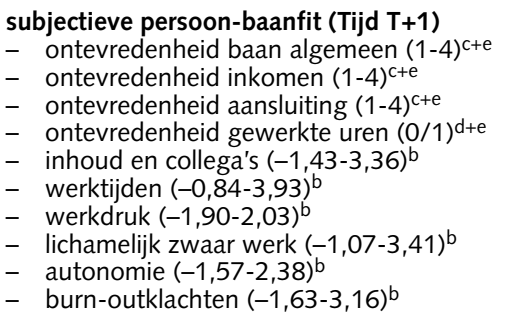 & $\begin{array}{l}-1,04^{* *} \\
-0,31^{* *} \\
-0,03 \\
-0,14 \\
-0,26^{* *} \\
-0,01 \\
-0,11 \sim \\
-0,14^{*} \\
0,07 \\
-0,17^{* *}\end{array}$ & $\begin{array}{l}-0,48^{* *} \\
-0,20^{*} \\
0,06 \\
-0,14 \\
-0,17^{*} \\
-0,01 \\
0,04 \\
0,03 \\
-0,08 \\
-0,10\end{array}$ \\
\hline $\begin{array}{l}\text { a Modellen zijn gecorrigeerd voor de volgende kenmer } \\
\text { beëindiging cursussen, contract, beroepsstatus, inkon } \\
\text { b Lineaire regressie. } \\
\text { c Geordende logistische regressie. } \\
\text { d Logistische regressie. } \\
\text { e Zie noot a bij tabel } 2 . \\
\sim p<0,10 . \\
\text { * } p<0,05 . \\
* * 0<01 .\end{array}$ & $\begin{array}{l}\text { baankenmerk, lee } \\
\text { tte, sector percent }\end{array}$ & $\begin{array}{l}\text { acht, leeftijd kinderen, burgerlijke staat, opleidingsniveau, } \\
\text { loosheid en percentage economische groei. }\end{array}$ \\
\hline
\end{tabular}

uitvallen, ook al verdient deze werknemer geen euro meer. Het kan er dan enkel aan liggen dat het takenpakket in de nieuwe baan beter in overeenstemming is met het daaraan gekoppelde inkomen. Naarmate werknemers meer ervaring binnen hun bedrijf krijgen, gebruiken werkgevers ze vaker voor meer taken, zonder dat daar een financiële vergoeding tegenover hoeft te staan. De reden dat bij een vrijwillige functiewisseling wel een objectieve verhoging van het inkomen wordt gevonden, zou dan kunnen zijn dat deze wisselingen veel vaker officiële interne promoties behelzen, met een verzwaring van het takenpakket en de bijbehorende loonsverhoging.

De resultaten van het rendement van vrijwillige externe mobiliteit laten zien dat ze wel degelijk leidt tot een vermindering van belastende lichamelijk zware arbeid. En deze bevinding is opvallend in het licht van de eerdere uitkomst dat werknemers die dergelijke belasting ervaren, juist minder vaak mobiel zijn dan zij die deze belasting minder ervaren. Het lijkt erop alsof deze groep werknemers de kansen lager inschat dan ze daadwerkelijk zijn.
Tot slot blijkt werkdruk vooral te verminderen door een andere werkgever te zoeken, maar zijn mensen die werkdruk ervaren vooral vrijwillig intern mobiel. Deze discrepantie in bevindingen kan ontstaan omdat werknemers die veel werkdruk ervaren en geestelijk zwaar werk verrichten, vaak de inhoudelijk meer uitdagende banen bezetten. Werkdruk is dan geen ongunstige kwalificatie van een baankenmerk, maar is eerder gewoon 'part of the job'. De grotere kans op interne mobiliteit duidt dan mogelijk op de kans dat mensen in uitdagende banen, die daar hard voor werken, ook vaker de mogelijkheid krijgen op de interne loopbaanladder te stijgen. Dat zij vervolgens niet minder werkdruk gaan ervaren, is niet zo vreemd. Blijkbaar is er ook nog een groep die de werkdruk echt ontvlucht door te veranderen van werkgever. De resultaten tonen aan dat dit, gezien de afname die dan plaatsvindt, geen onzinnige strategie is.

\section{Conclusie}

Deze bijdrage had als doel met longitudinale gegevens vast te stellen in welke mate 
Nederlandse werknemers vrijwillig van baan, dan wel van functie veranderen, in hoeverre een lage score op objectieve baankenmerken en een ongunstig gewaardeerde subjectieve persoon-baanfit vrijwillige mobiliteit in de hand werken en in welke mate deze vrijwillige intragenerationele mobiliteit rendement oplevert.

Analyses op longitudinale gegevens uit het OSA-Arbeidsaanbodpanel laten in de eerste plaats zien dat vrijwillige mobiliteit vaak voorkomt, zeker in tijden dat de algemene werkloosheid laag is en de economische groei hoog. Vanuit de arbeidspsychologie werd vervolgens de verwachting geformuleerd dat een geringe overeenstemming tussen gewenste en feitelijke baankenmerken ervoor zorgt dat werknemers de voorkeur ontwikkelen om een andere, betere plaats op de arbeidsmarkt te verwerven. Onder controle van diverse andere determinanten van vrijwillige mobiliteit bleken niet de objectieve hoogte van het inkomen en de beroepsstatus, maar factoren als ontevredenheid over het inkomen, de aansluiting tussen vaardigheden en de inhoud van het werk, het aantal werkuren, de kans op vrijwillige mobiliteit te verhogen. Dit gold eveneens voor een ongunstige waardering van de baan wat betreft inhoud en collega's en werkdruk. Ontevredenheid over de baan in het algemeen was meestal de sterkste predictor van de kans op vrijwillige mobiliteit. Zeer waarschijnlijk komt dit doordat de score op deze indicator het eindoordeel is van een werknemer, nadat alle negatieve en positieve aspecten tegen elkaar zijn afgewogen. Maar ongunstige subjectieve baankenmerken gelden dus als sterke pushfactoren om de huidige baan te verlaten, met de verwachting het op een andere plaats beter te krijgen.

Deze verwachting blijkt niet ongegrond, gezien het rendement dat vrijwillige mobiliteit oplevert, zowel wat betreft objectieve baankenmerken als inkomen en beroepsstatus, als wat betreft baankenmerken die we onder het kopje 'subjectieve persoon-baanfit' hebben geplaatst. Vrijwillige baanwisselingen leiden tot een stijging van de beroepsstatus, functiewisselingen verhogen zowel de status als het inkomen. Door wisseling van werkgever neemt de ontevredenheid over het inkomen af, over de inhoud en de collega's, vermindert de ervaren werkdruk, de belasting die lichamelijk zwaar werk met zich meebrengt en nemen burn-outklachten af. Door wisseling van functie binnen het bedrijf neemt eveneens de ontevredenheid over het inkomen af, als ook de ongunstige waardering van de inhoud van de baan en collega's. Zowel interne als externe mobiliteit levert daarom uiteindelijk ook een behoorlijke toename van algemene baantevredenheid op. Daarmee draagt vrijwillige mobiliteit niet alleen bij aan het plezier waarmee werknemers deelnemen aan het arbeidsproces, maar indirect waarschijnlijk ook aan het functioneren van de algehele economie.

\section{Noten}

1 Ook allochtonen hadden hier genoemd kunnen worden. Doordat in de OSA-bestanden allochtonen onvoldoende zijn vertegenwoordigd, blijven ze in de analyse buiten beschouwing.

2 Het is niet direct duidelijk of de uitval van panelleden selectief is voor de variabele vrijwillige mobiliteit. Immers, voor degenen die in het panel blijven, weten we of ze mobiel zijn geweest in de twee jaar voorafgaande aan het peilmoment (bijvoorbeeld tussen 2002 en 2000). Voor degenen die het panel hebben verlaten, weten we alleen of ze mobiel waren in de twee jaar voorafgaande aan het voorlaatste peilmoment, dus in dit voorbeeld tussen 1998 en 2000. Maar stel dat het vooral mobiele werknemers zijn die meer dan niet-mobiele werknemers het panel verlaten, dan leidt dit tot een onderschatting van de samenhang tussen baankenmerken en mobiliteit en eveneens tot een onderschatting van het rendement van mobiliteit. Dan zijn de gepresenteerde schattingen dus conservatieve weergaven van de werkelijkheid.

3 De volgende items/vragen zijn uit de analyse verwijderd vanwege onvoldoende hoge communaliteiten of vanwege dubbelladingen: (1) ontevredenheid over gewerkte uren, (2) ontevredenheid over type contract, (3) lopendebandwerk belastend?, (4) werken met mensen belastend?, (5) werken buiten eigen vakgebied belastend?, (6) weet wat er op het werk wordt verwacht, (7) repetitief werk belastend? en (8) werktijden sluiten goed aan op thuis.

4 We laten de resultaten met betrekking tot deze controlevariabelen verder onbesproken. 


\section{Literatuur}

Althauser, R.P. \& A.L. Kalleberg (1990). Identifying Career Lines and Internal Labor Markets Within Firms: A Study in the Interrelationships of Theory and Methods. In: R.L. Breiger (ed.). Social Mobility and Social Structure (pp. 308-356). Cambridge: Cambridge University Press.

Baron, J.N. \& W.T. Bielby (1984). The Organization of Work in a Segmented Economy. American Sociological Review, 49, 454-473.

Becker, G. (1964). Human Capital: A Theoretical and Empirical Analysis, with Special Reference to Education. New York: National Bureau of Economic Research.

Beer, P.T. de (2001). Over werken in de postindustriële samenleving. Den Haag: Sociaal en Cultureel Planbureau.

Blossfeld, H.-P. (1986). Career Opportunities in the Federal Republic of Germany: A Dynamic Approach to the Study of Life-course, Cohort, and Period Effects. European Sociological Review, 2, 208-225.

Dagevos, J.M. (1998). Begrensde mobiliteit: over allochtone werkenden in Nederland (proefschrift). Assen: Van Gorcum.

DiPrete, T., et al. (1997). Collectivist versus Individualist Mobility Regimes? Structural Change and Job Mobility in Four Countries. American Journal of Sociology, 103, 318-358.

Dwyer, R.E. (2004). Downward Earnings Mobility after Voluntary Employer Exits. Work and Occupations, 31, 111-139.

Felmlee, D.H. (1982). Women's Job Mobility Processes within and between Employers. American Sociological Review, 47, 142-151.

Fouarge, D., A. Gielen, R. Grim, M. Kerkhofs, A. Román, J. Schippers \& T. Wilthagen (2006). Trendrapport aanbod van arbeid 2005. Tilburg: Organisatie voor Strategisch Arbeidsmarktonderzoek.

Gaspersz, J. \& Ott, M. (1997). Management van employability. Nieuwe kansen in arbeidsrelaties. Assen: Van Gorcum.

Gesthuizen, M. (2004). The Life-course of the Loweducated in the Netherlands: Social and Economic Risks. Nijmegen: Radboud Universiteit Nijmegen.

Gesthuizen, M. \& J.M. Dagevos (2005). Arbeidsmobiliteit in goede banen: oorzaken van baanen functiewisselingen en gevolgen voor de kenmerken van het werk. Den Haag: Sociaal en Cultureel Planbureau.
Glebbeek, A. (1993). Perspectieven op loopbanen. Assen: van Gorcum.

Graaf, P.M. de \& R. Luijckx (1997). Structurele veranderingen, aspiraties en arbeidsmobiliteit. OSA-werkdocument W155. Den Haag: OSA.

Johnson, M. (2001). Change in Job Values During the Transition to Adulthood. Work and Occupations, 28, 315-345.

Judge, T.A., C.J. Thoresen, J.E. Bono \& G.K. Patton (2001). The Job Satisfaction-Job Performance Relationship: A Qualitative and Quantitative Review. Psychological Bulletin, 127, 376-407.

Kalleberg, A.L. (1977). Work Values and Job Rewards: A Theory of Job Satisfaction. American Sociological Review, 42, 124-143.

Kalleberg, A.L. \& A. Mastekaasa (2001). Satisfied Movers, Committed Stayers. The Impact of Job Mobility on Work Attitudes in Norway. Work and Occupations, 28, 183-209.

Keith, K. \& McWilliams, A. (1997). Job Mobility and Gender-Based Wage Growth Differentials. Economic Inquiry, 3, 320-333.

Kraaykamp, G. \& M. Kalmijn (1997). Beloningsverschillen tussen mannelijke en vrouwelijke managers. Tijdschrift voor Arbeidsvraagstukken, 13, 216-229.

Kristof-Brown, A.L., R.D. Zimmerman \& E.C. Johnson (2005). Consequences of Individuals' Fit at Work: A Meta-Analysis of Person-Job, PersonOrganisation, Person-Group, and PersonSupervisor Fit. Personnel Psychology, 58, 281342.

Layard, R. (2005). Happiness. Lessons From a New Science. London: Penguin Books.

Mincer, J. (1974). Schooling, Experience, and Earnings. New York: Columbia University Press.

Rosenfeld, R.A. (1992). Job Mobility and Career Processes. Annual Review of Sociology, 18, 3961.

Sørensen, A.B. (1975). The Structure of Intragenerational Mobility. American Sociological Review, 40, 456-471.

Stinchcombe, A.L. (1979). Social Mobility in Industrial Labor Markets. Acta Sociologica, 22, 217-245

Tolbert, P.S. \& P. Moen (1998). Men's and Women's Definitions of 'Good' Jobs. Work and Occupations, 25, 168-194.

Wright, T.A. \& R. Cropanzano (2000). Psychological Well-being and Job Satisfaction as Predictors of Job Performance. Journal of Occupational Health Psychology, 5, 84-94. 